\title{
German Public Support for Tobacco Control Policy Measures: Results from the German Study on Tobacco Use (DEBRA), a Representative National Survey
}

\author{
Melanie Boeckmann ${ }^{1, *(1)}$, Daniel Kotz ${ }^{1,2}$ (D), Lion Shahab ${ }^{2}$, Jamie Brown ${ }^{2}$ (D) \\ and Sabrina Kastaun ${ }^{1}$ \\ 1 Institute of General Practice, Addiction Research and Clinical Epidemiology Unit, Medical Faculty of the \\ Heinrich-Heine-University, 40227 Düsseldorf, Germany; daniel.kotz@med.uni-duesseldorf.de (D.K.); \\ sabrina.kastaun@med.uni-duesseldorf.de (S.K.) \\ 2 Department of Behavioural Science and Health, University College London, London WC1E 6BT, UK; \\ lion.shahab@ucl.ac.uk (L.S.); jamiebrown10@gmail.com (J.B.) \\ * Correspondence: boeckmannmelanie@gmail.com or melanie.boeckmann@med.uni-duesseldorf.de; \\ Tel.: +49-211-540-84-234
}

Received: 15 February 2018; Accepted: 29 March 2018; Published: 7 April 2018

\begin{abstract}
Smoking prevalence in Germany remains high at approximately $28 \%$. We assessed public support for tobacco legislation and associations between level of support and smoking and socio-demographic characteristics. Data from 2087 people were collected as part of the German Study on Tobacco Use ("DEBRA"): a nationally representative, face-to-face household survey. Public support was measured on total ban of sale, raising the minimum age for sales, taxation of tobacco industry sales, research into e-cigarettes, and ban of smoking in cars when children are present. Associations were assessed with multivariate logistic regression. Over $50 \%$ of the German population support taxing industry profits $(57.3 \%)$ and assessing e-cigarettes as an aid to quit smoking (55.5\%). Over $40 \%$ support raising the legal age of sale $(43.1 \%)$, and $22.9 \%$ support a total ban on tobacco sales. A smoking ban in cars when children are present was most popular $(71.5 \%)$, even among current smokers $(67.0 \%)$. There is public support for stricter tobacco control measures in Germany. A smoking ban in cars when children are present could be a feasible policy to implement.
\end{abstract}

Keywords: tobacco control; policy; epidemiology; public opinion; survey

\section{Introduction}

Tobacco smoking is highly addictive and a major risk factor for mortality and morbidity. Compared with other high-income European countries, smoking prevalence in Germany is high at approximately $28 \%$ [1], and $14 \%$ of the country's mortality can be attributed to smoking [2]. More than 120,000 people in Germany die from tobacco-related illness each year [2], and second-hand smoke exposure for children and adolescents, while reduced over the past decades, remains a problem [3], particularly in families with lower incomes and a poorer educational background [4]. It is estimated that up to $27 \%$ of all hospitalisations for diagnoses of asthma, respiratory diseases, or otitis media in children younger than five years can be attributed to passive smoking [5]. Smoking remains a significant public health issue in Germany; yet tobacco control in Germany continues to be contested. Germany was among the ten countries with the largest population of smokers in 2015, with an age-standardised estimated number of 7.1 million female and 9.2 million male smokers [6]. The tobacco industry continues to be highly active in German tobacco-related legislation [7-9]. Owing to Germany's 
strong economic position within the E.U., the country's tobacco control efforts are also interesting to other European countries.

Tobacco control legislation is a cornerstone of the World Health Organization (WHO) Framework Convention on Tobacco Control (FCTC), and Germany, together with 179 other countries, has ratified the convention, thus pledging to implement laws and measures to decrease tobacco use prevalence [10]. Germany has a minimum age of sale for tobacco products of 18 years, tobacco products are taxed, and pictorial health warnings were introduced in 2016 [11], but comprehensive implementation has not yet been achieved [12]. Advertisement of tobacco products outdoors, at points of sale, and in cinemas and indoor smoking in certain bars and pubs are all still allowed [9]. Other European countries have made substantial progress in protecting non-smokers from second-hand smoke exposure. A number of European nations, including Italy [13], Finland [14], England [15], Wales [16], and Ireland [17] have introduced laws to ban smoking in private vehicles when minors are present. Even though the German Medical Association and political representatives, such as the Drug Commissioner of the Federal Government of Germany, have expressed an urgent need for such a ban in Germany [18], smoking in cars with children is still allowed.

Treatment for tobacco addiction is not reimbursed by German health insurance companies, forcing patients to bear the costs themselves $[19,20]$. This may influence the likelihood of smokers actually trying to stop smoking with evidence-based methods [21]. Indeed, most smokers in Germany still try to quit smoking unaided or with the use of non-evidence-based treatments $[22,23]$ and therefore have a very low chance to succeed. Electronic cigarettes (EC) could be promising devices to aid in smoking cessation, partly because they are relatively cheap and less harmful [24-26] compared with regular cigarettes and easily accessible even for those on lower incomes [27]. However, e-cigarette use is not without risk [28-30], and information on the long-term effects of use is currently still lacking [31]. A recent review on the impact of e-cigarettes on smoking cessation showed that good-quality studies assessing the topic are often lacking, yet the few high-quality studies we have do seem to indicate potential for e-cigarettes as a cessation tool [32,33]. These findings echo those of previous Cochrane reviews $[27,31]$. There is widespread concern about e-cigarettes acting as a gateway to cigarettes for younger people. Numerous prospective studies have established that adolescents who have tried e-cigarettes are more likely to report subsequent smoking after adjustment for important factors $[25,34,35]$. There is disagreement on the extent to which the adjustment for the likely common liability is sufficient [36]. Reassuringly, there is not yet population-level evidence in countries where e-cigarettes have become popular of long-term declines in cigarette smoking uptake being undermined [26]. Further surveillance and investigation is required, including context-specific studies on the German healthcare system. Views of the German public on e-cigarette safety and efficacy as cessation aid have also not been studied conclusively.

Data from the Tobacco Control Ranking Scale in 2016 show that Germany is at place 34 out of 35 countries in successful tobacco control implementation in Europe [9]. As studies have shown that price increases and taxation, limited access to tobacco products, second-hand smoke exposure restrictions, and plain packaging all contribute to lowering smoking prevalence in European countries [9], less advanced tobacco control and high smoking prevalence are correlated [37]. Tobacco control is thus a promising avenue for better public health, which also applies in Germany.

Policymakers may be convinced that more restrictive legislation on tobacco use and access is unpopular among their constituency, which could be influencing their policies. Public support for public health measures is therefore an interesting item to measure for a better understanding of links between being personally affected and one's endorsement of legislative changes. Findings from the English Smoking Toolkit Study, for example, show that broad public support for price raises of cigarettes or even a total ban on tobacco product sales exists, even among current smokers [38,39]. Similarly, a representative survey study from the U.S. found widespread support for large cigarette pack warning labels among both smokers and non-smokers [40]. Recent findings on public support for the 2013 smoking ban in restaurant and bars in the German federal state of North-Rhine Westphalia 
suggest that the state's population largely agrees with the restriction and supports limiting second-hand smoke exposure [41]. Schaller et al. similarly found evidence of support among the German population for non-smoking legislation in public places, in particular regarding smoking in cars when children are present [42]. Considering Germany's high level of smoking prevalence, limited political commitment to full FCTC implementation, and subsequent high burden of disease, more representative data on public perceptions of tobacco control are needed to improve our understanding of opportunities for structural prevention. This article reports representative survey data on the public support for five possible legislative changes in Germany: a total ban on the sale of tobacco products, raising the minimum age for tobacco sales, taxation of tobacco industry sales, research into e-cigarettes as tobacco cessation aids, and legislation to curb children's second-hand smoke exposure in cars.

\section{Materials and Methods}

\subsection{Data and Participants}

Data were taken from the German Study on Tobacco Use [23] (DEBRA: "DEutsche Befragung zum RAuchverhalten"), an ongoing representative household survey on tobacco use in Germany. DEBRA has been registered in the German Clinical Trials Register (registration number DRKS00011322), and the study protocol has been published elsewhere [43]. Details about recruitment and sampling strategies for the DEBRA study are described in the study protocol [43]. In brief, every two months a new representative sample of $\sim 2000$ respondents aged 14 years and older completes a computer-assisted, face-to-face survey. A multi-stage, multi-stratified random probability sampling approach is used. Fieldwork is conducted by the market research institute Kantar Health Munich, Germany, and per wave up to 280 trained interviewers conduct on average 7 interviews each. Respondents report data on demographics and the use of tobacco and EC, with smokers additionally answering detailed questions about smoking behaviour, quit attempts, exposure to health professionals' advice on quitting, and use of cessation aids [1]. Questions on support for tobacco control policies were added to wave two of the survey in September 2016. A total of 2087 respondents participated in this wave of the survey.

\subsection{Measures}

\subsubsection{Policy Questions}

Respondents were asked to indicate whether they supported the following statements [43]:

1. "The sale of cigarettes and tobacco in Germany should be banned completely within the next 10 years."

2. "The legal age of sale of cigarettes and tobacco in Germany should be raised from 18 to 21."

3. "Tobacco industry sales should be taxed in order to use the money to address problems caused by tobacco (e.g., health issues, environmental problems, etc.)."

4. "It should be assessed whether e-cigarettes are safe and effective in assisting smokers to quit."

5. "When minor children are in the car, smoking inside the car should be banned and subjected to punishment."

Answering options were:

1. "Strongly support"

2. "Tend to support"

3. "No opinion either way"

4. "Tend to oppose"

5. "Strongly oppose"

6. "No answer"

We re-coded answering options 1 and 2 into "agree", 4 and 5 into "disagree", and 3 as "undecided" for the descriptive statistics. For the regression analyses, we dichotomised answers into "agree" 
(strongly support, tend to support) and "don't agree" (no opinion, tend to oppose, strongly oppose). This allowed for comparison of our results with those of prior analyses of the English Smoking Toolkit Study $[38,39]$.

\subsubsection{Socio-Demographic Characteristics}

Self-reported data on age, sex, education, respondent and net household income, and employment status were collected. We measured socio-economic status with the two most relevant indicators in the regression model: net income, categorised as $1=$ less than $1000 € /$ month $2=1000$-less than $2000 € /$ month, $3=2000$-less than $3000 € /$ month, $4=3000$-less than $4000 € /$ month, $5=4000$-less than $5000 € /$ month $6=$ more than $5000 € /$ month, and education, categorised from lowest to highest attainment as 1 = no qualification, 2 = junior high school equivalent ("Hauptschulabschluss"), 3 = secondary school equivalent ("Realschulabschluss"), $4=$ advanced technical college equivalent ("Fachhochschulreife"), 5 = high school equivalent ("Allgemeine Hochschulreife").

\subsubsection{Smoking Characteristics}

Participants were categorised as current smokers if they smoked cigarettes (including hand-rolled) or any other combustible tobacco (e.g., pipe or cigar) daily or occasionally; as ex-smokers if they had stopped in the last year or more than a year ago; and as never smokers if they had never been a smoker (i.e., never smoked for a year or more). Current smokers were asked to also indicate the number of cigarettes smoked daily, weekly, or monthly, whether they made a quit attempt in the past year, and about their motivation to stop smoking using the translated and culturally adapted German version of the Motivation to Stop Smoking Scale (in German: "Motivation zum Rauchstopp Skala", MRS) $[43,44]$.

\subsection{Analyses}

We carried out descriptive statistics to characterise the sample and to establish prevalence rates for support per policy question, reported for the total sample and separately for current smokers, ex-smokers, and non-smokers. The sample was weighted to be representative of the German population for calculation of the primary outcome prevalence rates (support for policy measures). Associations between smoking status, socio-demographic characteristics, and support for policy measures were assessed using multivariate logistic regression with the dichotomous dependent variable "agree on a policy statement" (yes/no). Several pre-defined potential confounders were considered in the analyses: sex, age, net household income, education, smoking status, and, for a subgroup analysis of current smokers, smoking characteristics, such as attempts to quit during the past year, number of cigarettes smoked per day, and their current motivation to stop smoking. These associations were examined with unweighted data. Our approach to all analyses was exploratory.

Respondents with missing data on their smoking status were excluded from all analyses $(n=25$, $1.1 \%$ from the total sample). A total of 2062 respondents were thus included in the analysis. Furthermore, respondents who did not want to answer questions regarding the policy statements or those with missing data on their educational level or their attempts to quit smoking were excluded only from the multivariate logistic regression analyses (question $1=215$ missings $(10.4 \%$ ), question $2=185$ missings $(9 \%)$, question $3=194$ missings $(9.4 \%)$, question $4=240$ missings $(11.6 \%)$, question $5=162$ missings $(7.4 \%)$ ).

\section{Results}

Of the total sample of 2062 respondents, $586(28.1 \%$, 95\% confidence interval $(95 \% \mathrm{CI})=26-30 \%$; unweighted) were current smokers, 369 (17.7\%, 95\% CI = 16-19\%) ex-smokers, and 1107 (53.0\%, $95 \% \mathrm{CI}=51-55 \%$ ) never smokers. Baseline characteristics, including socio-demographic characteristics, are presented in Table 1 . The mean age was 51.8 years (standard deviation $(\mathrm{SD})= \pm 20$ ), and 1070 
$(51.9 \%)$ of the respondents were female. Smoking characteristics of the subsample of current smokers are presented as unweighted data in Table 2.

\subsection{Public Support for Tobacco Policy Measures}

Results, weighted to be representative for the German population, are presented in Figure 1. Of the total sample, $22.9 \%$ (95\% CI $=21.1-24.8 \%$ ) would support a total ban on the sale of tobacco and cigarettes within the next ten years, $21.8 \%(95 \% \mathrm{CI}=20.0-23.6 \%)$ were undecided on that matter, and almost half of the sample $(49.0 \%, 95 \% \mathrm{CI}=46.8-51.2 \%)$ disagreed with the proposed statement.

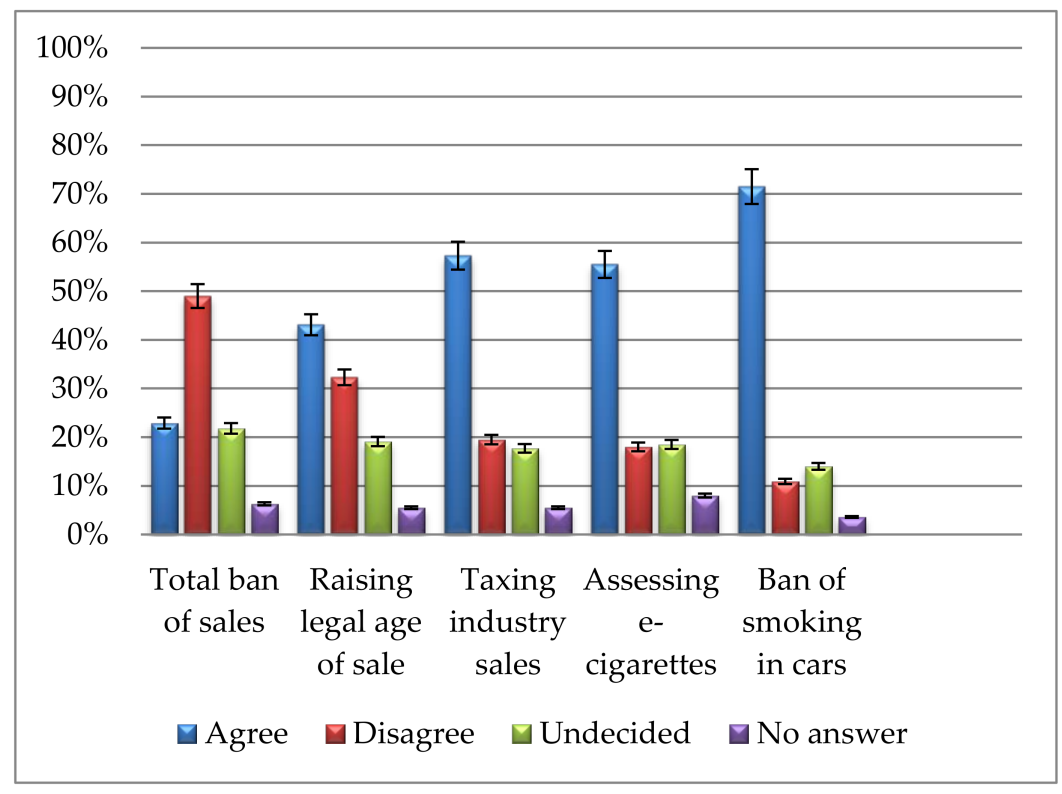

Figure 1. Proportion (and 95\% confidence intervals) of public support for the five tobacco policy measures with the re-coded answer options agree (strongly support, tend to support), disagree (strongly oppose, tend to oppose), undecided (no opinion either way), or no answer ( $n=2062$ respondents).

Raising the legal age of sale from 18 to 21 would be supported by $43.1 \%$ (95\% CI $=41.0-45.3 \%)$ of the respondents, whereas $32.3 \%$ of the respondents $(95 \% \mathrm{CI}=30.3-34.4 \%)$ disagreed with the proposed statement on such a policy change.

A large majority of respondents $(71.5 \%, 95 \% \mathrm{CI}=69.5-73.5 \%)$ would support a total ban in cars when minors are present; only $10.9 \%(95 \% \mathrm{CI}=9.5-12.3 \%)$ disagreed with this statement.

Among the subsample of current smokers (weighted subsample $n=542), 9.9 \%$ (95\% CI $=7.4-12.5 \%$ ) would support a total ban on the sale of tobacco and cigarettes within the next ten years. Also, $10.3 \%$ $(95 \% \mathrm{CI}=7.8-12.9 \%)$ were undecided if they would support such a total ban, and nearly three-quarters of the sample $(74.0 \%, 95 \% \mathrm{CI}=70.5-77.9 \%)$ disagreed with the proposed statement.

More than half of the smokers were either supportive $(34.6 \%, 95 \% \mathrm{CI}=30.7-38.7 \%)$ or undecided on the question $(18.4 \%, 95 \% \mathrm{CI}=15.2-21.7 \%)$ of whether the legal age of sale should be raised from 18 to 21 .

Half of smokers $(50.1 \%, 95 \% \mathrm{CI}=46.0-54.4 \%)$ agreed on the importance of assessing the effectiveness and safety of e-cigarettes as an aid to quit smoking tobacco, while $21.7 \%(95 \% \mathrm{CI}=18.3-25.2 \%)$ and $24.3 \%$ $(95 \% \mathrm{CI}=20.7-28.0 \%)$ were undecided or disagreed with this statement, respectively.

Comparable with the total sample, the majority of current smokers $(67.0 \%, 95 \% \mathrm{CI}=63.0-70.9 \%)$ would support a total ban in cars when minors are present; only $14.4 \%(95 \% \mathrm{CI}=11.4-17.3 \%)$ disagreed with this statement. 
Table 1. Unweighted baseline characteristics of the total sample, and by smoking status.

\begin{tabular}{|c|c|c|c|c|}
\hline & $\begin{array}{c}\text { Total Sample } \\
(n=2062 ; 100 \%)\end{array}$ & $\begin{array}{l}\text { Current Smoker } \\
(n=586 ; 28.4 \%)\end{array}$ & $\begin{array}{c}\text { Ex-Smoker } \\
(n=369 ; 17.9 \%)\end{array}$ & $\begin{array}{c}\text { Never Smoker } \\
(n=1107 ; 53.7 \%)\end{array}$ \\
\hline Age, years (mean \pm SD) & $51.8 \pm 19.8$ & $47.1 \pm 17.2$ & $58.4 \pm 17.5$ & $52.1 \pm 21.1$ \\
\hline \multicolumn{5}{|l|}{ Sex } \\
\hline Female & $1070(51.9 \%)$ & $271(46.2 \%)$ & $143(38.8 \%)$ & $656(59.3 \%)$ \\
\hline Male & $992(48.1 \%)$ & $315(53.8 \%)$ & $226(61.2 \%)$ & $451(40.7 \%)$ \\
\hline \multicolumn{5}{|l|}{ Education ${ }^{+}$} \\
\hline High school equiv. & $479(23.2 \%)$ & $110(19.2 \%)$ & $85(23.2 \%)$ & $284(27.4 \%)$ \\
\hline Adv. tech. college equiv. & $133(6.5 \%)$ & $28(4.9 \%)$ & $30(8.2 \%)$ & $75(7.2 \%)$ \\
\hline Secondary school equiv. & $686(33.3 \%)$ & $230(40.1 \%)$ & $116(31.7 \%)$ & $340(32.8 \%)$ \\
\hline Junior high school equiv. & $646(31.3 \%)$ & $193(33.6 \%)$ & $130(35.5 \%)$ & $323(31.1 \%)$ \\
\hline No qualification & $33(1.6 \%)$ & $13(2.3 \%)$ & $5(1.4 \%)$ & $15(1.4 .5 \%)$ \\
\hline \multicolumn{5}{|l|}{ Household income } \\
\hline$>€ 5000 /$ per month & $134(6.5 \%)$ & $26(4.4 \%)$ & $27(7.3 \%)$ & $81(7.3 \%)$ \\
\hline$€ 4000-5000 /$ per month & $128(6.2 \%)$ & $31(5.3 \%)$ & $24(6.5 \%)$ & $73(6.6 \%)$ \\
\hline$€ 3000-4000 /$ per month & $369(17.9 \%)$ & $96(16.4 \%)$ & $67(18.2 \%)$ & $206(18.6 \%)$ \\
\hline$€ 2000-3000 /$ per month & $557(27.0 \%)$ & $164(28.0 \%)$ & $106(28.7 \%)$ & $287(25.9 \%)$ \\
\hline$€ 1000-2000 /$ per month & $638(30.9 \%)$ & $173(29.5 \%)$ & $117(31.7 \%)$ & $348(31.4 \%)$ \\
\hline$<€ 1000 /$ per month & $236(11.4 \%)$ & $96(16.4 \%)$ & $28(7.6 \%)$ & $112(10.1 \%)$ \\
\hline
\end{tabular}

Data are presented as number $(\%)$, unless otherwise stated. ${ }^{\dagger}$ German equivalents to education levels listed in table from highest to lowest: high school equivalent $=$ "Allgemeine Hochschulreife", advanced technical college equivalent = "Fachhochschulreife", secondary school equivalent = "Realschulabschluss", junior high school equivalent = "Hauptschulabschluss". 
Table 2. Unweighted smoking characteristics of current smokers.

\begin{tabular}{cc}
\hline & $\begin{array}{c}\text { Current Smokers Only } \\
(\boldsymbol{n}=\mathbf{5 8 6})\end{array}$ \\
\hline Cigarettes smoked per day (mean \pm SD) & $15.3 \pm 9.0$ \\
Made at least one quit attempt last year & $140(23.9 \%)$ \\
Motivation to stop smoking (MRS) [43] & $268(45.7 \%)$ \\
Do not want to stop smoking & $139(23.7 \%)$ \\
Should stop but do not really want to & $52(8.9 \%)$ \\
Want to stop but have not thought about when & $51(8.7 \%)$ \\
Want to stop but have not decided when & $43(7.3 \%)$ \\
Really want to stop and hope to soon & $7(1.2 \%)$ \\
Really want to stop and intend to in the next 3 months & $6(1.0 \%)$ \\
Really want to stop and intend to in the next month
\end{tabular}

Data are presented as number (\%), unless otherwise stated.

\subsection{Results from the Regression Analysis}

Results of the unweighted multivariate logistic regression for each of the five policy statements are presented in Table 3 (for the total sample), Table 4 (for the subgroup of current smokers), and Table 5 (for the subgroup of ex- and never-smokers). We found no associations between sex, education, or household income and support for policy measures. With increasing age (in 10-year-units), overall support for these policy recommendations decreased.

\subsubsection{Support for a Total Ban on Tobacco Sales}

Support for a total ban on tobacco sales was associated with smoking status. Never-smokers and ex-smokers were significantly more likely to indicate their support for a total ban on tobacco sales than current smokers (odds ratio (OR) 5.26, CI 3.80-7.28 and OR 3.48, CI 2.37-5.11, respectively).

Among current smokers, respondents who had not tried to quit in the past year were less likely to support a total ban on sales than respondents who indicated that they had tried to quit (OR 0.20, CI 0.10-0.40). Motivation to quit smoking did not show significant associations with support for a total ban.

\subsubsection{Support for Raising the Legal Age of Sale}

Support for raising the legal age of sale from 18 to 21 was also dependent on smoking status: never-smokers and ex-smokers were more likely to support this measure than current smokers (OR 2.73, CI 2.17-3.46 and OR 1.75, CI 1.30-2.35, respectively).

Among current smokers, higher levels of motivation to stop smoking (OR 1.11, CI 1.02-1.20) were associated with greater support of this policy.

\subsubsection{Support for Special Taxation of Tobacco Industry Profits}

Men were marginally less likely to support taxation of industry profits than women (OR 0.81 , CI 0.66-0.99). Never- and ex-smokers were more likely to support the proposed measure than current smokers (OR 4.16, CI 3.29-5.24 and OR 3.48, CI 2.59-4.66, respectively).

Among current smokers, all income categories had a lower likelihood of supporting taxation compared with the highest income earning group (see Table 4). 
Table 3. Multivariate associations with support (agree/totally agree) for the policy statements in the total sample $(n=2062)$.

\begin{tabular}{|c|c|c|c|c|c|}
\hline & Banning Sale of Tobacco & $\begin{array}{l}\text { Raising Legal Age of } \\
\text { Sale from } 18 \text { to } 21\end{array}$ & $\begin{array}{l}\text { Taxing Tobacco Industry Sales, to } \\
\text { Address Tobacco-Related Problems }\end{array}$ & $\begin{array}{l}\text { Assessing Effectiveness and } \\
\text { Safety of E-Cigarettes }\end{array}$ & $\begin{array}{l}\text { Banning Smoking in Cars } \\
\text { When Minors Are Present }\end{array}$ \\
\hline \multicolumn{6}{|l|}{ Smoking status } \\
\hline Current smoker (ref.) & 1 & 1 & 1 & 1 & 1 \\
\hline Ex-smoker & $3.48(2.37-5.11)^{* * *}$ & $1.75(1.31-2.36)^{* * *}$ & $3.48(2.59-4.66)^{* * *}$ & $1.39(1.04-1.85)$ * & $1.29(0.95-1.74)$ \\
\hline Never-smoker & $5.26(3.80-7.28) * * *$ & $2.73(2.17-3.46) * * *$ & $4.16(3.30-5.24)^{* * *}$ & $1.50(1.20) * * *$ & $1.81(1.42-2.31)^{* * * *}$ \\
\hline Age, 10 -year units a & $0.98(0.92-1.04)$ & $0.95(0.89-1.00) *$ & $1.02(0.96-1.08) *$ & $0.94(0.89-0.99) *$ & $0.94(0.89-1.00) *$ \\
\hline \multicolumn{6}{|l|}{ Sex } \\
\hline Female (reference) & 1 & 1 & 1 & 1 & 1 \\
\hline Male & $0.83(0.66-1.03)$ & $0.84(0.69-1.02)$ & $0.81(0.66-0.99) *$ & $0.88(0.72-1.07)$ & $0.89(0.72-1.10)$ \\
\hline \multicolumn{6}{|l|}{ Education $^{+}$} \\
\hline High school equiv. (ref.) & 1 & 1 & 1 & 1 & 1 \\
\hline Adv. tech. college equiv. & $1.59(1.00-2.51)$ & $1.19(0.79-1.801)$ & $0.86(0.56-1.33)$ & $1.15(0.75-1.75)$ & $1.28(0.79-2.07)$ \\
\hline Secondary school equiv. & $1.15(0.85-1.56)$ & $1.14(0.88-1.48)$ & $0.81(0.62-1.07)$ & $0.79(0.61-1.02)$ & $0.97(0.73-1.29)$ \\
\hline Junior high school equiv. & $1.31(0.94-1.83)$ & $1.31(0.99-1.74)$ & $0.65(0.49-0.88)^{* *}$ & $0.80(0.60-1.06)$ & $1.10(0.81-1.51)$ \\
\hline No qualification & $0.89(0.33-2.39)$ & $2.00(0.91-4.40)$ & $0.99(0.42-2.32)$ & $0.37(0.16-0.85)^{*}$ & $0.86(0.37-2.00)$ \\
\hline \multicolumn{6}{|l|}{ Household income } \\
\hline$€>5000 /$ per month (ref.) & 1 & 1 & 1 & 1 & 1 \\
\hline$€ 4000-5000 /$ per month & $1.13(0.62-2.05)$ & $1.08(0.64-1.82)$ & $0.68(0.39-1.19)$ & $1.18(0.71-1.97)$ & $0.78(0.43-1.42)$ \\
\hline$€ 3000-4000 /$ per month & $0.81(0.49-1.35)$ & $1.10(0.71-1.69)$ & $0.72(0.45-1.16)$ & $1.13(0.74-1.73)$ & $0.75(0.45-1.23)$ \\
\hline$€ 2000-3000 /$ per month & $1.14(0.71-1.83)$ & $1.11(0.73-1.68)$ & $0.56(0.35-0.87)^{* * *}$ & $1.31(0.87-1.97)$ & $0.71(0.44-1.15)$ \\
\hline$€ 1000-2000 /$ per month & $1.28(0.80-2.07)$ & $1.25(0.83-1.90)$ & $0.77(0.49-1.21)$ & $1.63(1.08-2.47)^{*}$ & $0.75(0.47-1.22)$ \\
\hline$<€ 1000 /$ per month & $1.48(0.86-2.53)$ & $1.56(0.98-2.50)$ & $0.86(0.52-1.43)$ & $1.65(1.03-2.65)^{*}$ & $1.15(0.66-2.01)$ \\
\hline \multicolumn{6}{|c|}{$\begin{array}{l}\text { Data are presented as adjusted odds ratio (OR) }\left(95 \% \text { confidence interval around OR). }{ }^{*} p<0.05 ;{ }^{* *} p<0.01 ;{ }^{* * *} p<0.001 .{ }^{\text {a }} \text { Continuous variable. }{ }^{+} \text {German equivalents to education level }\right. \\
\text { listed in table from highest to lowest: high school equivalent = "Allgemeine Hochschulreife", advanced technical college equivalent }=\text { "Fachhochschulreife", secondary school equivalent } \\
\text { "Realschulabschluss", junior high school equivalent = "Hauptschulabschluss". Age units are based on DEBRA study participation eligibility (14 and older): 14-23; 24-33; 34-43; 44-5 } \\
\text { 54-63; 64-73; 74-83; 84-93; 94-103. }\end{array}$} \\
\hline & Banning Sale of Tobacc & $\begin{array}{l}\text { Raising Legal Age of } \\
\text { Sale from } 18 \text { to } 21\end{array}$ & $\begin{array}{l}\text { Taxing Tobacco } \\
\text { Industry Sales }\end{array}$ & $\begin{array}{l}\text { sing Effectiveness and Safety } \\
\text { of E-Cigarettes }\end{array}$ & $\begin{array}{c}\text { Banning Smoking in Cars When } \\
\text { Minors Are Present }\end{array}$ \\
\hline \multirow{2}{*}{\multicolumn{6}{|c|}{$\begin{array}{l}\text { Cgarettes smoked/day, number } \\
\text { Quit attempt last year (yes/no) }\end{array}$}} \\
\hline & & & & & \\
\hline Yes, attempt to quit (reference) & 1 & 1 & 1 & 1 & 1 \\
\hline No, attempt to quit & $0.20(0.10-0.40)^{* * *}$ & $0.94(0.59-1.50)$ & $0.71(0.45-1.11)$ & $1.07(0.69-1.65)$ & $0.96(0.61-1.52)$ \\
\hline Motivation to stop smoking (MRS) b & $1.06(0.95-1.18)$ & $1.11(1.02-1.20)$ * & $1.00(0.92-1.08)$ & $1.01(0.93-1.10)$ & $1.02(0.94-1.12)$ \\
\hline Age, 10 -year units a & $0.89(0.73-1.10)$ & $0.85(0.75-0.96)^{* *}$ & $0.92(0.82-1.04)$ & $0.98(0.87-1.09)$ & $1.01(0.90-1.14)$ \\
\hline
\end{tabular}


Table 4. Cont.

\begin{tabular}{|c|c|c|c|c|c|}
\hline & Banning Sale of Tobacco & $\begin{array}{l}\text { Raising Legal Age of } \\
\text { Sale from } 18 \text { to } 21\end{array}$ & $\begin{array}{l}\text { Taxing Tobacco } \\
\text { Industry Sales }\end{array}$ & $\begin{array}{l}\text { Assessing Effectiveness and Safety } \\
\text { of E-Cigarettes }\end{array}$ & $\begin{array}{l}\text { Banning Smoking in Cars When } \\
\text { Minors Are Present }\end{array}$ \\
\hline \multicolumn{6}{|l|}{ Sex } \\
\hline Female (ref.) & 1 & 1 & 1 & 1 & 1 \\
\hline Male & $0.58(0.28-1.17)$ & $0.84(0.56-1.28)$ & $0.93(0.62-1.39)$ & $0.76(0.52-1.11)$ & $0.56(0.37-0.84)^{* *}$ \\
\hline \multicolumn{6}{|l|}{ Education $^{+}$} \\
\hline High school equiv. (ref.) & 1 & 1 & 1 & 1 & 1 \\
\hline Advanced technical college equiv. & $0.60(0.07-5.36)$ & $1.95(0.69-5.52)$ & $0.61(0.21-1.76)$ & $1.62(0.52-5.02)$ & $1.33(0.43-4.15)$ \\
\hline Secondary school equiv. & $0.50(0.19-1.35)$ & $1.11(0.60-2.05)$ & $0.63(0.37-1.09)$ & $0.67(0.39-1.15)$ & $1.14(0.65-2.00)$ \\
\hline Junior high school equiv. & $1.05(0.39-2.80)$ & $1.79(0.95-3.36)$ & $0.50(0.28-0.89)^{*}$ & $0.63(0.35-1.11)$ & $1.44(0.79-2.62)$ \\
\hline No qualification & $2.97(0.45-19.82)$ & $4.82(1.31-17.79)$ * & $0.73(0.19-2.79)$ & $0.47(0.13-1.71)$ & $1.88(0.45-7.86)$ \\
\hline \multicolumn{6}{|l|}{ Household income } \\
\hline$€>5000 /$ per month (ref.) & 1 & 1 & 1 & 1 & 1 \\
\hline$€ 4000-5000 /$ per month & $1.37(0.19-10.12)$ & $0.97(0.23-4.01)$ & $0.22(0.07-0.88) *$ & $0.48(0.14-1.69)$ & $0.84(0.19-3.81)$ \\
\hline$€ 3000-4000 /$ per month & $0.78(0.14-4.40)$ & $1.23(0.41-3.72)$ & $0.71(0.25-1.98)$ & $0.77(0.28-2.11)$ & $0.70(0.21-2.39)$ \\
\hline$€ 2000-3000 /$ per month & $0.46(0.09-2.53)$ & $0.84(0.29-2.50)$ & $0.31(0.11-0.85)^{*}$ & $0.92(0.35-2.45)$ & $0.48(0.15-1.55)$ \\
\hline$€ 1000-2000 /$ per month & $0.57(0.11-3.10)$ & $1.22(0.42-3.56)$ & $0.47(0.17-1.26)$ & $1.30(0.49-3.47)$ & $0.44(0.14-1.43)$ \\
\hline$<€ 1000 /$ per month & $0.53(0.09-3.14)$ & $1.17(0.39-3.57)$ & $0.34(0.12-0.97)$ * & $0.80(0.29-2.20)$ & $0.59(0.17-1.98)$ \\
\hline \multicolumn{6}{|c|}{ 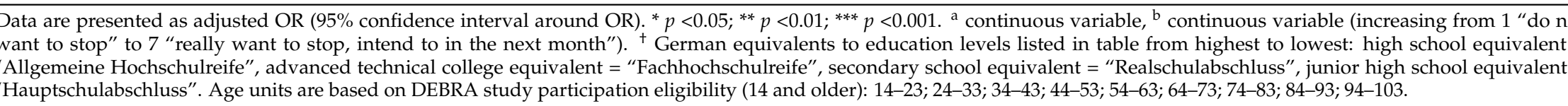 } \\
\hline & Banning Sale of Tobacco & $\begin{array}{l}\text { Raising Legal Age of } \\
\text { Sale from } 18 \text { to } 21\end{array}$ & $\begin{array}{l}\text { Taxing Tobacco } \\
\text { Industry Sales }\end{array}$ & $\begin{array}{l}\text { Assessing Effectiveness and Safety } \\
\text { of E-Cigarettes }\end{array}$ & $\begin{array}{c}\text { Banning Smoking in Cars When } \\
\text { Minors Are Present }\end{array}$ \\
\hline Age, 10 -year units a & $0.98(0.92-1.05)$ & $0.97(0.91-1.03)$ & $1.04(0.98-1.12)$ & $0.93(0.87-0.99) *$ & $0.92(0.85-0.98) *$ \\
\hline \multicolumn{6}{|l|}{ Sex } \\
\hline Female (ref.) & 1 & 1 & 1 & 1 & 1 \\
\hline Male & $0.83(0.65-1.10)$ & $0.82(0.66-1.02)$ & $0.79(0.62-1.00)$ & $0.95(0.75-1.20)$ & $1.02(0.79-1.31)$ \\
\hline \multicolumn{6}{|l|}{ Education $^{\dagger}$} \\
\hline High school equiv. (ref.) & 1 & 1 & 1 & 1 & 1 \\
\hline Advanced technical college equiv. & $1.55(0.95-2.53)$ & $1.14(0.72-1.81)$ & $0.93(0.56-1.53)$ & $1.13(0.70-1.84)$ & $1.30(0.74-2.29)$ \\
\hline Secondary school equiv. & $1.20(0.86-1.66)$ & $1.20(0.88-1.60)$ & $0.82(0.59-1.13)$ & $0.84(0.61-1.14)$ & $0.90(0.64-1.27)$ \\
\hline Junior high school equiv. & $1.25(0.87-1.79)$ & $1.21(0.87-1.68)$ & $0.66(0.46-0.94)$ * & $0.87(0.61-1.23)$ & $0.97(0.66-1.42)$ \\
\hline No qualification & $0.61(0.19-1.98)$ & $1.18(0.43-3.25)$ & $0.84(0.26-2.74)$ & $0.20(0.10-0.68)^{*}$ & $0.64(0.21-1.96)$ \\
\hline
\end{tabular}


Table 5. Cont.

\begin{tabular}{|c|c|c|c|c|c|}
\hline & Banning Sale of Tobacco & $\begin{array}{l}\text { Raising Legal Age of } \\
\text { Sale from } 18 \text { to } 21\end{array}$ & $\begin{array}{l}\text { Taxing Tobacco } \\
\text { Industry Sales }\end{array}$ & $\begin{array}{l}\text { Assessing Effectiveness and Safety } \\
\text { of E-Cigarettes }\end{array}$ & $\begin{array}{c}\text { Banning Smoking in Cars When } \\
\text { Minors Are Present }\end{array}$ \\
\hline \multicolumn{6}{|l|}{ Household income } \\
\hline$€>5000 /$ per month (ref.) & 1 & 1 & 1 & 1 & 1 \\
\hline$€ 4000-5000 /$ per month & $1.00(0.53-1.88)$ & $1.16(0.65-2.07)$ & $0.88(0.46-1.69)$ & $1.44(0.80-2.61)$ & $0.81(0.41-1.60)$ \\
\hline$€ 3000-4000 /$ per month & $0.72(0.42-1.23)$ & $1.00(0.61-1.57)$ & $0.66(0.39-1.12)$ & $1.24(0.77-2.01)$ & $0.75(0.43-1.31)$ \\
\hline$€ 2000-3000 /$ per month & $1.17(0.71-1.93)$ & $1.15(0.72-1.82)$ & $0.62(0.37-1.04)$ & $1.35(0.85-2.16)$ & $0.82(0.48-1.41)$ \\
\hline$€ 1000-2000 /$ per month & $1.34(0.82-2.21)$ & $1.23(0.77-1.94)$ & $0.84(0.50-1.41)$ & $1.60(1.00-2.56)$ & $0.96(0.56-1.67)$ \\
\hline$<€ 1000 /$ per month & $1.64(0.91-2.94)$ & $1.84(1.10-3.18)$ & $1.23(0.65-2.33)$ & $2.38(1.31-4.32)^{* *}$ & $1.76(0.86-3.60)$ \\
\hline
\end{tabular}

Data are presented as adjusted OR ( $95 \%$ confidence interval around OR). ${ }^{*} p<0.05 ;{ }^{* *} p<0.01$; ${ }^{a}$ continuous variable, ${ }^{\dagger}$ German equivalents to education levels listed in table from highest to lowest: high school equivalent = "Allgemeine Hochschulreife", advanced technical college equivalent = "Fachhochschulreife", secondary school equivalent $=$ "Realschulabschluss", junior high school equivalent = "Hauptschulabschluss". Age units are based on DEBRA study participation eligibility (14 and older): 14-23; 24-33; 34-43; 44-53; 54-63; 64-73; 74-83; 84-93; 94-103. 


\subsubsection{Support for Assessing the Effectiveness and Safety of EC as Cessation Aids}

Never-smokers and ex-smokers had $50 \%$ and $40 \%$ higher odds, respectively, of supporting assessing the effectiveness and safety of EC compared with current smokers (OR 1.50, CI 1.19-1.87 and OR 1.39, CI 1.04-1.85, respectively). Within the subsample of current smokers, no associations were found.

\subsubsection{Support for Ban on Smoking in Cars When Children Are Present}

Never-smokers were more likely than current smokers to support the ban on smoking in cars (OR 1.81, CI 1.41-2.31); however, no such association could be found when comparing ex-smokers with current smokers. Among the smoker subsample, men were about half as likely to support a ban on smoking in cars when minors are present as women (OR 0.55, CI 0.37-0.84).

\section{Discussion}

Our results indicate that a substantial share of the German population would support stricter tobacco control policies than those currently implemented. Of the five suggested policy measures, three were supported by more than half of the population: taxing industry sales, assessing e-cigarettes, and ban on smoking in cars when children are present. Over $40 \%$ also supported raising the legal age of sale. Twenty percent of the population would support a total ban on tobacco products in Germany within ten years.

A total ban on the sale of tobacco is a quite intrusive measure yet appeals to $20 \%$ of the population. Among smokers, however, only 10\% would support a total ban of sales. The proposed measure of banning smoking in cars when a child is present received the highest-70\%-support in the German population. Even among the subsample of smokers, $67 \%$ indicated their support for a smoking ban in cars. A similarly high level of support for this policy has previously been reported for Germany [42], and also for the U.K., Australia, Canada, and the United States [45]. Tobacco control measures are generally also supported in the European population [46,47].

Smoking status was associated with whether or not a person agrees with a policy measure. Never-smokers and ex-smokers were consistently more likely to support a control policy than current smokers across all proposed measures. Motivation to quit only showed a significant association with support for one measure: raising the legal age of sale. Motivation to quit seems to play a less important role in shaping German smokers' opinion towards more restrictive tobacco control policies.

Supporting a tobacco control measure was generally not significantly associated with sex, education, or income, with a few exceptions. With increasing age (in 10-year-units), overall support for these policy recommendations decreased. The lack of a clear socio-demographic pattern for supporting policies echoes findings from England on price increases of tobacco [39], and suggests that tobacco control objectives are shared across social gradients and gender. Participants who state that they are undecided on whether to support a policy may be susceptible to information campaigns or targeted health education. It would be worth exploring how to target these groups specifically.

Comparing our study with findings from the U.K. Smoking Toolkit Study, our results show that there is currently less support for a total ban in Germany (22\%) than in England in 2008 (44\%) [38]. Given the associations between support and smoking status, some of the difference is likely associated with the higher smoking prevalence in Germany. There is also higher public acceptance of smoking bans in public places in the U.K. [48]. Other studies from the European context have similarly shown that overall, public support for tobacco control exists [49], including for smoking bans in outdoor spaces surrounding hospitals or schools [50] as well as for total smoking bans [51]. Support for price increases varies: whereas the English public seems to agree with tax increases [39], support in European countries with lower GDPs has declined in past years [49]. Our results do not show associations with socio-demographic characteristics, yet a recent study by Filippidis et al. [52] raises the possibility of associations between political views and support for tobacco control. Further insights 
into reasons behind these variations by European country might be useful for coherent European tobacco control strategies.

As Germany is a federal country, a coordinated policy approach across state lines might be needed to fully implement additional tobacco control measures. For these analyses, we did not assess responses by individual states as the sample sizes per state were too small for statistical analyses. A total ban on sales within a country in Europe also needs to consider European regulations, and must aim to avoid unintended negative consequences of a complete ban. Even less restrictive tobacco control measures have been shown to contribute to reduced smoking prevalence [53,54], which in turn may lead to decreased public expenditure on tobacco-related morbidity, fewer tobacco-related deaths [55], and better population health. Policymakers in Germany could therefore consider first implementing those measures garnering wider support in the population.

This study has some important limitations. We were only able to analyse data from one wave of the survey that included the policy support questions. It would be interesting to compare results longitudinally to assess whether public support changes over time. We were interested in broad attitudes towards tobacco control policies that are not currently implemented in Germany. How the public would react to the actual implementation of measures cannot be inferred from our results. We also did not provide participants with suggestions on how such measures would be implemented: the hypothetical nature of these policies may have influenced responses. We were unable to include more than five policy-related questions into the survey wave so as to not overburden participants. Future survey waves would ideally also elicit information on support for additional measures, such as indoor smoking bans in public housing, which have recently been implemented in the United States [56].

Despite these limitations, our results suggest a first, feasible step forward in tobacco control in Germany would be instituting a smoking ban in cars when children are present. Starting with a seemingly non-controversial policy implementation may prepare the way for future implementation of more contested measures.

\section{Conclusions}

Public support for additional tobacco control measures is moderately high in Germany. A smoking ban in private vehicles if children are present is supported by a majority of the population (over $70 \%$ ), even among smokers $(67.0 \%)$. These findings indicate that implementation of such a policy that already exists in other European countries might also be feasible in Germany.

Acknowledgments: The DEBRA study is funded by the Ministry for Innovation, Science, and Research of the German Federal State of North Rhine-Westphalia ("NRW-Rückkehrprogramm"). Jamie Brown's salary is funded by a programme grant from Cancer Research UK (C1417/A22962). Open Access costs are covered by UCL. The authors would like to thank Robert West for support with the DEBRA study design. The DEBRA study has been approved by the Ethics Committee at the Heinrich-Heine-University Duesseldorf, Germany (ID 5386/R) and has been registered at the German Clinical Trials Register (DRKS00011322).

Author Contributions: M.B. drafted the manuscript and interpreted the data. D.K. conceived the DEBRA study, acquired funding, contributed to the study design for the policy question analysis, interpreted the data, and contributed to the writing of the manuscript. L.S. and J.B. work for the English Smoking Toolkit Study with which DEBRA is closely aligned, and contributed to the writing of the manuscript. S.K. coordinates the DEBRA study, analysed the data, interpreted the data, and co-wrote the manuscript.

Conflicts of Interest: L.S. has received honoraria for talks, an unrestricted research grant, and travel expenses to attend meetings and workshops by pharmaceutical companies that make smoking cessation products (Pfizer, Johnson \& Johnson), and has acted as paid reviewer for grant awarding bodies and as a paid consultant for health care companies. Other research has been funded by the government, a community-interested company (National Centre for Smoking Cessation), and charitable sources. J.B. has received unrestricted smoking cessation research funding from Pfizer. The other authors declare no conflicts of interest. The funding sponsors had no role in the design of the study; in the collection, analyses, or interpretation of data; in the writing of the manuscript, and in the decision to publish the results. All authors declare no financial links with tobacco companies or e-cigarette manufacturers or their representatives. 


\section{References}

1. Kotz, D.; Boeckmann, M.; Kastaun, S. The use of tobacco, e-cigarettes, and methods to quit smoking in Germany-A representative study using 6 waves of data over 12 months (the DEBRA study). Dtsch. Ärzteblatt Int. 2018, 115, 235-242.

2. Mons, U.; Kahnert, S. Neuberechnung der tabakattributablen Mortalität-Nationale und regionale Daten für Deutschland (Recalculation of Tobacco-Attributable Mortality: National and Regional Data for Germany). Das Gesundheitswes. 2017. [CrossRef]

3. Kuntz, B.; Lampert, T. Smoking and Passive Smoke Exposure Among Adolescents in Germany. Dtsch. Arztebl. Int. 2016, 113, 23-30. [PubMed]

4. Bolte, G.; Fromme, H. Socioeconomic determinants of children's environmental tobacco smoke exposure and family's home smoking policy. Eur. J. Public Health 2008, 19, 52-58. [CrossRef] [PubMed]

5. Thyrian, J.R.; Hanke, M.; Hannöver, W.; Grempler, J.; Röske, K.; Fusch, C.; John, U. Tabakrauchexposition in der Wohnung und stationäre Behandlungen von Kindern unter 5 Jahren in Deutschland [Exposure to tobacco smoke (passive smoking) in the home and inpatient treatment of children under the age of 5 years in Germany]. DMW Dtsch. Medizinische Wochenschrift 2005, 130, 1189-1194. [CrossRef] [PubMed]

6. Reitsma, M.B.; Fullman, N.; Ng, M.; Salama, J.S.; Abajobir, A.; Abate, K.H.; Abbafati, C.; Abera, S.F.; Abraham, B.; Abyu, G.Y. Smoking prevalence and attributable disease burden in 195 countries and territories, 1990-2015: A systematic analysis from the Global Burden of Disease Study 2015. Lancet 2017, 389, 1885-1906. [CrossRef]

7. Grüning, T.; Strünck, C.; Gilmore, A. Puffing Away? Explaining the Politics of Tobacco Control in Germany. Ger. Polit. 2008, 17, 140-164. [CrossRef]

8. Grüning, T.; Gilmore, A. Germany: Tobacco industry still dictates policy. Tob. Control 2007, 16, 2. [PubMed]

9. Joossens, L.; Raw, M. The Tobacco Control Scale 2016 in Europe; European Commission: Brussels, 2017.

10. Framework Convention Alliance Parties to the WHO FCTC (Ratifications and Accessions). Available online: http:/ / www.fctc.org/about-fca/tobacco-control-treaty/latest-ratifications / parties-ratificationsaccessions (accessed on 14 December 2017).

11. Hefler, M. Germany: The tide to turn with graphic health warnings? Worldwide news and comment. Tob. Control 2016, 25, 263-266.

12. Grüning, T.; Weishaar, H.; Collin, J.; Gilmore, A.B. Tobacco industry attempts to influence and use the German government to undermine the WHO Framework Convention on Tobacco Control. Tob. Control 2012, 21, 30-38. [CrossRef] [PubMed]

13. Reuters Staff Italy Cracks Down on Smokers as Tough Law Takes Effect. Available online: http:/ / www. reuters.com/article/us-health-italy-smoking-idUSKCNOVB1I3 (accessed on 14 December 2017).

14. Hofverberg, E. Finland: New Tobacco Law Adopted with Intent of Eliminating Tobacco Use. Available online: http: / / www.loc.gov /law / foreign-news / article/ finland-new-tobacco-law-adopted-with-intentof-eliminating-tobacco-use/ (accessed on 14 December 2017).

15. Triggle, N. Car Smoking Ban Comes into Force. Available online: http://www.bbc.com/news/health34402622 (accessed on 14 December 2017).

16. Welsh Government Ban on Smoking in Cars Carrying Children Begins. Available online: http:/ /gov.wales / newsroom/health-and-social-services/2015/151001ban/?lang=en (accessed on 14 December 2017).

17. Ireland Department of Health Varadkar Announces Start Date for Smoking Ban in Cars Where Children Are Present. Available online: http:/ /health.gov.ie/blog/press-release/varadkar-announces-start-date-forsmoking-ban-in-cars-where-children-are-present/ (accessed on 14 December 2017).

18. Neue Kampagne Soll Kinder vor Passivrauchen im Auto Schützen (New Campaign Supposed to Protect Children from Smoke Exposure in Cars). Available online: https:/ / www.aerzteblatt.de/nachrichten/69788/ Neue-Kampagne-soll-Kinder-vor-Passivrauchen-im-Auto-schuetzen (accessed on 14 December 2017).

19. Batra, A. Treatment of tobacco dependence. Dtsch. Arztebl. Int. 2011, 108, 555-564. [PubMed]

20. Twardella, D.; Brenner, H. Effects of practitioner education, practitioner payment and reimbursement of patients' drug costs on smoking cessation in primary care: A cluster randomised trial. Tob. Control 2007, 16, 15-21. [CrossRef] [PubMed]

21. Reda, A.A.; Kaper, J.; Fikretler, H.; Severens, J.L.; van Schayck, C.P. Healthcare financing systems for increasing the use of tobacco dependence treatment. Cochrane Database Syst. Rev. 2009, CD004305. 
22. Kröger, C.; Gradl, S. Tabakentwöhnungsmaßnahmen in Deutschland. Bundesgesundheitsblatt Gesundheitsforsch. Gesundheitsschutz 2010, 53, 201-206. [CrossRef] [PubMed]

23. DEBRA Study. Available online: www.debra-study.info (accessed on 22 August 2017).

24. Shahab, L.; Goniewicz, M.L.; Blount, B.C.; Brown, J.; McNeill, A.; Alwis, K.U.; Feng, J.; Wang, L.; West, R. Nicotine, Carcinogen, and Toxin Exposure in Long-Term E-Cigarette and Nicotine Replacement Therapy Users. Ann. Intern. Med. 2017, 166, 390. [CrossRef] [PubMed]

25. National Academies of Sciences, Engineering, and Medicine. Public Health Consequences of E-Cigarettes; Stratton, K., Kwan, L.Y., Eaton, D.L., Eds.; The National Academies Press: Washington, DC, USA, 2018; ISBN 978-0-309-46831-2.

26. Public Health England. Evidence Review of E-Cigarettes and Heated Tobacco Products 2018: Executive Summary; Public Health England: London, UK, 2018.

27. McRobbie, H.; Bullen, C.; Hartmann-Boyce, J.; Hajek, P. Electronic cigarettes for smoking cessation and reduction. Cochrane Database Syst. Rev. 2014, CD010216.

28. Wilson, N.; Hoek, J.; Thomson, G.; Edwards, R. Should e-cigarette use be included in indoor smoking bans? Bull. World Health Organ. 2017, 95, 540-541. [CrossRef] [PubMed]

29. Hess, I.; Lachireddy, K.; Capon, A. A systematic review of the health risks from passive exposure to electronic cigarette vapour. Public Heal. Res. Pract. 2016. [CrossRef] [PubMed]

30. World Health Organization. Electronic Nicotine Delivery Systems and Electronic Non-Nicotine Delivery Systems (ENDS/ENNDS); World Health Organization: Geneva, Switzerland, 2016.

31. Hartmann-Boyce, J.; McRobbie, H.; Bullen, C.; Begh, R.; Stead, L.F.; Hajek, P. Electronic cigarettes for smoking cessation. Cochrane Database Syst. Rev. 2016. [CrossRef] [PubMed]

32. Villanti, A.C.; Feirman, S.P.; Niaura, R.S.; Pearson, J.L.; Glasser, A.M.; Collins, L.K.; Abrams, D.B. How do we determine the impact of e-cigarettes on cigarette smoking cessation or reduction? Review and recommendations for answering the research question with scientific rigor. Addiction 2018, 113, 391-404. [CrossRef] [PubMed]

33. Beard, E.; West, R.; Michie, S.; Brown, J. Association between electronic cigarette use and changes in quit attempts, success of quit attempts, use of smoking cessation pharmacotherapy, and use of stop smoking services in England: time series analysis of population trends. BMJ 2016, 354, i4645. [CrossRef] [PubMed]

34. Coleman, B.N.; Apelberg, B.J.; Ambrose, B.K.; Green, K.M.; Choiniere, C.J.; Bunnell, R.; King, B.A. Association Between Electronic Cigarette Use and Openness to Cigarette Smoking Among US Young Adults. Nicotine Tob. Res. 2015, 17, 212-218. [CrossRef] [PubMed]

35. Persoskie, A.; O’Brien, E.K.; Nguyen, A.B.; Tworek, C. Measuring youth beliefs about the harms of e-cigarettes and smokeless tobacco compared to cigarettes. Addict. Behav. 2017, 70, 7-13. [CrossRef] [PubMed]

36. Kozlowski, L.T.; Warner, K.E. Adolescents and e-cigarettes: Objects of concern may appear larger than they are. Drug Alcohol Depend. 2017, 174, 209-214. [CrossRef] [PubMed]

37. Gallus, S.; Lugo, A.; La Vecchia, C.; Boffetta, P.; Chaloupka, F.J.; Colombo, P.; Currie, L.; Fernandez, E.; Fischbacher, C.; Gilmore, A.; et al. Pricing Policies And Control of Tobacco in Europe (PPACTE) project. Eur. J. Cancer Prev. 2014, 23, 177-185. [CrossRef] [PubMed]

38. Shahab, L.; West, R. Public support in England for a total ban on the sale of tobacco products. Tob. Control 2010, 19, 143-147. [CrossRef] [PubMed]

39. Gardner, B.; West, R. Public support in England for raising the price of cigarettes to fund tobacco control activities. Tob. Control 2010, 19, 331-333. [CrossRef] [PubMed]

40. Kowitt, S.D.; Noar, S.M.; Ranney, L.M.; Goldstein, A.O.; Bach, L.; Brewer, N.; Holder-Hayes, E.; Day, H. Public attitudes toward larger cigarette pack warnings: Results from a nationally representative U.S. sample. PLoS One 2017, 12, e0171496. [CrossRef] [PubMed]

41. Deutsches Krebsforschungszentrum (DKFZ). Nichtraucherschutz in Nordrhein-Westfalen: Akzeptanz in der Bevölkerung und Auswirkungen auf die Gastronomie [Protection from Second-Hand Smoke Exposure in Northrhine-Westphalia: Public Support and Effects on Gastronomy]; Deutsches Krebsforschungszentrum (DKFZ): Heidelberg, Germany, 2017.

42. Schaller, K.; Braun, S.; Pötschke-Langer, M. Erfolgsgeschichte Nichtraucherschutz in Deutschland: Steigende Unterstützung in der Bevölkerung für gesetzliche Maßnahmen (Success story protection from second-hand smoke exposure in Germany: Increased public support for legislative measures). Gesundheitsmonitor Newsl. 2014, 4, 1-9. 
43. Kastaun, S.; Brown, J.; Brose, L.S.; Ratschen, E.; Raupach, T.; Nowak, D.; Cholmakow-Bodechtel, C.; Shahab, L.; West, R.; Kotz, D. Study protocol of the German Study on Tobacco Use (DEBRA): A national household survey of smoking behaviour and cessation. BMC Public Health 2017, 17, 378. [CrossRef] [PubMed]

44. Kotz, D.; Brown, J.; West, R. Predictive validity of the Motivation To Stop Scale (MTSS): A single-item measure of motivation to stop smoking. Drug Alcohol Depend. 2013, 128, 15-19. [CrossRef] [PubMed]

45. Hitchman, S.C.; Fong, G.T.; Zanna, M.P.; Hyland, A.; Bansal-Travers, M. Support and correlates of support for banning smoking in cars with children: Findings from the ITC Four Country Survey. Eur. J. Public Health 2011, 21, 360-365. [CrossRef] [PubMed]

46. European Commission. Special Eurobarometer 458: Attitudes of Europeans towards Tobacco and Electronic Cigarettes; European Commission: Brussels, Belgium, 2017.

47. European Commission. Special Eurobarometer 385: Attitudes of Europeans towards tobacco; European Commission: Brussels, Belgium, 2012.

48. Patterson, C.; Semple, S.; Wood, K.; Duffy, S.; Hilton, S. A quantitative content analysis of UK newsprint coverage of proposed legislation to prohibit smoking in private vehicles carrying children. BMC Public Health 2015, 15, 760. [CrossRef] [PubMed]

49. Filippidis, F.T.; Agaku, I.T.; Vardavas, C.I.; Majeed, A. The association between economic recession and public support for increased tobacco taxation in 27 European countries. Scand. J. Public Health 2014, 42, 589-592. [CrossRef] [PubMed]

50. Sureda, X.; Fernandez, E.; Martinez-Sanchez, J.M.; Fu, M.; Lopez, M.J.; Martinez, C.; Salto, E. Secondhand smoke in outdoor settings: Smokers' consumption, non-smokers' perceptions, and attitudes towards smoke-free legislation in Spain. BMJ Open 2015, 5, e007554. [CrossRef] [PubMed]

51. Lykke, M.; Pisinger, C.; Glümer, C. Ready for a goodbye to tobacco?-Assessment of support for endgame strategies on smoking among adults in a Danish regional health survey. Prev. Med. (Baltim). 2016, 83, 5-10. [CrossRef] [PubMed]

52. Filippidis, F.T.; Girvalaki, C.; Mechili, E.-A.; Vardavas, C.I. Are political views related to smoking and support for tobacco control policies? A survey across 28 European countries. Tob. Induc. Dis. 2017, 15, 45. [CrossRef] [PubMed]

53. Currie, L.M.; Blackman, K.; Clancy, L.; Levy, D.T. The effect of tobacco control policies on smoking prevalence and smoking-attributable deaths in Ireland using the IrelandSS simulation model. Tob. Control 2013, 22, e25-e32. [CrossRef] [PubMed]

54. White, V.M.; Durkin, S.J.; Coomber, K.; Wakefield, M.A. What is the role of tobacco control advertising intensity and duration in reducing adolescent smoking prevalence? Findings from 16 years of tobacco control mass media advertising in Australia. Tob. Control 2015, 24, 198-204. [CrossRef] [PubMed]

55. Levy, D.T.; Blackman, K.; Currie, L.M.; Mons, U. Germany SimSmoke: The Effect of Tobacco Control Policies on Future Smoking Prevalence and Smoking-Attributable Deaths in Germany. Nicotine Tob. Res. 2013, 15, 465-473. [CrossRef] [PubMed]

56. Department of Housing and Urban Development. Instituting Smoke-Free Public Housing: Final rule; Federal Register: Washington, DC, USA, 2016; Vol. 81, pp. 87430-87444.

(C) 2018 by the authors. Licensee MDPI, Basel, Switzerland. This article is an open access article distributed under the terms and conditions of the Creative Commons Attribution (CC BY) license (http:// creativecommons.org/licenses/by/4.0/). 